\title{
Potential national economic benefits of the Food Insecurity and Nutrition Incentives Program of the U.S. Agricultural Act of 2014
}

\author{
Carolyn Dimitri ${ }^{\text {a* }}$ \\ New York University \\ Lydia Oberholtzer ${ }^{b}$ \\ Penn State University
}

Submitted August 7, 2014 / Revised December 10, 2014, and March 6, April 29, and April 30, 2015 /

Accepted April 30, 2015 / Published online July 30, 2015

Citation: Dimitri, C., \& Oberholtzer, L. (2015). Potential national economic benefits of the Food Insecurity and Nutrition Incentives Program of the U.S. Agricultural Act of 2014. Journal of Agriculture, Food Systems, and Community Development, 5(4), 49-61. http://dx.doi.org/10.5304/jafscd.2015.054.006

Copyright (C) 2015 by New Leaf Associates, Inc.

\begin{abstract}
The use of nutrition incentives in conjunction with federal nutrition benefits is intended in part to improve the diet of low-income consumers. The new program created by the U.S. Agricultural Act of 2014 is similar to the nutrition incentives that have been operated by select nonprofits and cities since the early part of the 2010s. The nutrition incentives as specified in the act will match redemptions of Supplemental Nutrition Assistance Program (SNAP) benefits and be used for

a $*$ Corresponding author: Carolyn Dimitri, Department of Nutrition, Food Studies and Public Health, New York University; 411 Lafayette Street; New York, NY 10003 USA; +1-212-992-7899; carolyn.dimitri@,nyu.edu

b Lydia Oberholtzer, Department of Agricultural Economics, Sociology, and Education, Penn State University; 103 Armsby; University Park, Pennsylvania 16802 USA; +1-301-891-0470; 1so3@psu.edu
\end{abstract}

purchasing only fruits and vegetables. In addition to the potential to provide health benefits, the proposed Food Insecurity and Nutrition Incentive Program may also create economic benefits. Extrapolations of data from a grassroots organization (Wholesome Wave) suggest that the economic benefits of the federal program are an estimated US\$58-US\$174 million per year, or 9222,767 jobs per year, depending on how the program is implemented. The effectiveness and impact of the program hinges on the capacity of participating retail outlets, the size of the matching nutrition incentive, and the types of outlets where the SNAP nutrition incentives can be redeemed.

\section{Keywords}

Agricultural Act of 2014, farm bill, federal nutrition benefits, SNAP, nutrition incentives, economic impacts 


\section{Introduction}

Federal nutrition policy is designed to enhance the food security of low-income households, with the bulk of benefits distributed to individuals and families via the Supplemental Nutrition Assistance Program (SNAP). Despite the strides federal programs have made in reducing hunger, obstacles to achieving a high-quality diet remain, with lowincome individuals experiencing high incidences of diet-related disease (Sugiyama \& Shapiro, 2014). This has prompted discussions among policymakers about incorporating "carrot and stick" approaches in policies to encourage consumers to eat less junk food and more fruits and vegetables (Barnhill, 2011; Blumenthal et al., 2014). One proposed "stick," restricting the use of food assistance by prohibiting purchases of junk food, was met with resistance (May, 2013). In contrast, a "carrot" proposed by advocates to encourage more fruit and vegetable purchasing was more successful, and the Agricultural Act of 2014 (the farm bill) created and funded a new food assistance program that provides incentives for purchasing fruits and vegetables, the Food Insecurity and Nutrition Incentives Program (FINI). The new "nutrition incentives" are funds distributed at the point of purchase; the incentives match a consumer's redemption of SNAP on fruits and vegetables, and are to be used for purchases of additional produce. Omitted from this discussion of policy levers is whether such policies have potential economic benefits for consumers beyond dietary changes.

The program is predicated on the premise that participating households will consume more fruits and vegetables if given incentives for doing so. The idea that people will eat more fruits and vegetables is intuitively appealing, but as the behavioral economics literature indicates, food choices are driven by more than just economic factors (see for example, Just, 2011). As a result, the Agricultural Act requires an evaluation of the efficacy of the program, asking whether those receiving nutrition incentives consume more fruits and vegetables. FINI's inclusion in the 2014 Act was the result of a lengthy political process and follows a mandate of the previous farm bill (2008) to conduct a pilot study evaluating the impact of nutrition incentives on fruit and vegetable consumption (Bartlett,
Klerman, Wilde, Olsho, Blocklin, Logan, \& Enver, 2013). While details were not specified in the Agricultural Act of 2014, the evaluation of FINI will likely follow the protocol established by the pilot study. An ancillary benefit of the FINI programin addition to the potential for better nutrition-is the ability to create new economic activity. The ability to influence economic activity, we argue, makes this federal program more powerful in that the unintended consequences of FINI may provide additional benefits to communities.

Federal funds authorized in the Agricultural Act of 2014 (US\$100 million over 5 years, with an additional US $\$ 5$ million per year until 2018) are to be awarded as grants by the U.S. Department of Agriculture (USDA), and the first request for applications for the FINI program was released in fall 2014 (USDA, NIFA, 2014). Current eligible organizations, under the rules of the act, are government agencies and nonprofit organizations. The act furthermore requires that the funds be used for programs that match SNAP benefits redeemed for fruits and vegetables (USDA, ERS, 2014). Other forms of federal nutrition assistance, such as those targeting specific groups, including women, infants, and children, and senior citizens, have been omitted from FINI. A possible explanation for this decision is maintaining simplicity of administration while reaching as many consumers as possible: in 2014, an average of 47 million people were receiving SNAP each month, in contrast to 8 million receiving WIC (USDA, FNS, 2015). By restricting the usage to SNAP, many people, along with their communities, can benefit from FINI, and the organizations administering the incentives are able to focus on providing the matches at the point of sale for just one federal nutrition benefit.

In many aspects, FINI is similar to programs currently administered by several nonprofit organizations and cities, where consumers receive a complete or partial match of federal benefits redeemed for fruit and vegetable purchases at participating farmers markets. The "double-coupon" or "healthy bucks" programs, as they are popularly called, have dual goals. The first is to improve the diet quality of low-income consumers, and more specifically underserved consumers who live in communities with limited access to healthy food. A second goal 
is to support local and regional farmers by developing new markets for them. Two of the key funding priorities in FINI preserve the spirit of the existing programs operated by cities and nonprofits: the focus on underserved communities and the preference for using funds to purchase locally and regionally produced fruits and vegetables. That said, FINI's impact on farmers and communities will ultimately depend on how the program is implemented, which will be a function of how the grant applicants propose using the funds in their communities and which organizations receive the funding.

The focus of policy-makers and researchers on potential benefits to consumers and farmers has spurred a growing body of literature. Recently published research examines the contribution of nutrition incentives to increased food access (Dimitri, Oberholtzer, \& Nischan, 2013; Schumacher, Nischan, \& Simon, 2011); benefits to farmers and farmers markets, including increased revenues to farmers (Baronberg, Dunn, Nonas, Dannefer, \& Sacks, 2013; Freedman, Mattison-Faye, Alia, Guest, \& Hébert, 2014; Lindsay et al., 2013; Oberholtzer, Dimitri, \& Schumacher, 2012); and to fruit and vegetable consumption (Dimitri, Oberholtzer, Zive, \& Sandolo, 2015; Klerman, Bartlett, Wilde, \& Olsho, 2014). A related body of research examines a broader question than how nutrition incentives influence farmers' revenues, and instead focuses on the relationship between farmers' use of local markets and farm success. Most research suggests that profits earned at farmers markets may be quite small, yet this general finding may be skewed by the fact that farmers directly marketing to consumers tend to have small farms and are likely to have a source of off-farm income (Low \& Vogel, 2011). Marketing exclusively through farmers markets is associated with lower gross farm income or earnings, while farm earnings for those who market through other local channels, or through multiple channels, were related to higher gross farm income (Park, Mishra, \& Wozniak, 2014; Uematsu \& Mishra, 2011). Growth in farmers markets in the Southeast, furthermore, was related to the higher profitability of farms marketing locally (Ahearn \& Sterns, 2013).

Overall, the research conducted to date suggests that many consumers and farmers perceive and realize positive benefits from the use of nutrition incentives. The research also suggests that the expansion of nutrition incentive programming into multiple channels (retail outlets in addition to farmers markets) may bring additional economic benefits to farmers.

Advocates argue that potential benefits to consumers and farmers are significant, but also point out that nutrition incentive programs may have a larger social impact in terms of economic activity and job creation (Andrés, 2014). The discussions tend to focus on the concept of buying locally, such as the recent campaign in Illinois that urges consumers to buy US $\$ 10$ of Illinois-raised food products in order to create a local reinvestment of US $\$ 2.4$ billion each year (Illinois Department of Agriculture, n.d.). The concept of community benefits is similarly reflected in the language of the SNAP program, which states "SNAP ...provides economic benefits to communities" (USDA, FNS, 2014). While the popular literature focuses on local spending, economic benefits can also be viewed from a national level, giving insight into the broad economic benefits of increased government spending rather than gains accruing to a specific community.

Quantifying economic benefits is an important component of community development research for both urban and rural communities. One method for doing so is the multiplier model, which recognizes that the effect of government spending on economic activity may be much higher than the initial injection of cash into the economy (Martinez et al., 2010). This paper adds to the literature on both economic benefits and nutrition incentives of the new FINI program and presents a policy analysis. In doing so, we discuss the potential national level economic benefits of the FINI program. The analysis draws on the 2012 experience of Wholesome Wave, one of the first nonprofits to operate nutrition incentive programs in underserved communities. ${ }^{1}$ Using its experience as a baseline, we address the potential economic impact of the new program, policy goals, and impacts on communities and research needs.

\footnotetext{
${ }^{1}$ See http://www.wholesomewave.org for more information on the organization.
} 


\section{Background on Grassroots Programs and Related Literature}

Several cities and nonprofit organization have extensive experience with nutrition incentives. Current programs are diverse, particularly in terms of the percent of federal nutrition benefits that are matched, and most face binding budget constraints. Some organizations match SNAP redemptions, dollar for dollar, up to a predetermined level, such as to US $\$ 20$ or US $\$ 25$ per visit (Fair Food Network, n.d.-a; Market Umbrella, 2012). Others match all purchases without a limit. Still others provide a 40 percent match (New York City), 50 percent match (Evanston, Illinois), or limit matches to lower amounts, such as US\$5 (Portland) or US $\$ 10$ (Boston) (SNAP to Health, n.d.). The USDA's Healthy Incentives Pilot, which was based on purchases of fruits and vegetables made in supermarkets, provided participants with a 30 percent match (Klerman et al., 2014). Many organizations are able to provide matches for only part of the season, until their grant funds run out (Market Umbrella, 2012). While some organizations match all types of farmers market-based federal nutrition benefits, others restrict usage to one form, such as SNAP.

One organization, Wholesome Wave, widely shares detailed information about its programs, which provides a useful starting point for the assessment of the new federal nutrition incentive program (Wholesome Wave, n.d.). Wholesome Wave's network includes hundreds of nutrition incentive programs in farmers markets across the country run by community organizations. The community-based organizations and markets that implement the programs have wide latitude in how the incentive programs are implemented in their markets; they decide which federal nutrition programs to match and how to administer the programs. The basic element is uniform across all markets: consumers receive an incentive that matches federal nutrition benefits when they buy fruits and vegetables at a participating farmers market. Variations in implementation include the amount a consumer can receive (some programs limit to US $\$ 5$ or US $\$ 10$ match per week), the percent of the match, and the type of nutrition assistance matched (SNAP, Senior FMNP, or women, infants and children [WIC FMNP and WIC CVV]).

Between 2009 and 2012 the number of markets sponsoring incentive programs in partnership with Wholesome Wave grew from 26 markets in 7 states and the District of Columbia to 306 markets in 24 states and the District of Columbia (see Table 1). During that time period, the average match ranged from 59 percent to 89 percent (note that these matches represent redeemed nutrition incentives, or the actual amounts spent by consumers). In 2009, the average dollar amount of federal nutrition benefit and incentives spent was nearly US $\$ 13,000$ per market; in 2012 the average was about US $\$ 7,800$ per market. In 2012, approximately US $\$ 1.5$ million of federal nutrition benefits were redeemed under these programs, along with matching nutrition incentives of about US $\$ 885,000$ (Table 1). The growth in the total number of farmers markets, federal nutrition benefits, and incentives was accompanied by declining matches (in terms of percent) as well as a decrease in the average federal nutrition benefits and incentives in dollars per market. In these early years of the nutrition incentives, the programs were available in markets with substantial organizational capacity and a strong motivation to serve underserved consumers, in locations with many federal nutrition benefit customers.

Under FINI, nutrition incentives will match redeemed SNAP benefits; thus the number of consumers eventually using nutrition incentives will depend on (1) how many vendors, farmers markets, and food stores accept SNAP, and (2) how many will accept FINI incentives. In comparison to food stores, where acceptance of federal nutrition benefits is common, only select farmers markets are equipped to accept federal nutrition benefits. Thus the USDA has actively promoted the use of federal nutrition benefits at farmers markets, with some success; in 2008, 750 farmers markets accepted federal nutrition benefits for payment, and in 2012, this number had increased to approximately 3,200 (USDA, FNS, 2013). In 2014, according to the USDA, about half of all farmers markets listed in the USDA Farmers Market Directory accepted federal nutrition benefits (USDA, AMS, 2013). As a result, redemption of federal nutrition benefits at farmers markets has grown (see Table 
Table 1: Federal Nutrition Benefits, Nutrition Incentives and Participating Farmers Markets: Wholesome Wave, 2009-2012 (all dollar values in US\$)

\begin{tabular}{lrrrr}
\hline Variable & $\mathbf{2 0 0 9}$ & $\mathbf{2 0 1 0}$ & $\mathbf{2 0 1 1}$ & $\mathbf{2 0 1 2}$ \\
\hline Federal nutrition benefits redeemed at farmers markets & $\$ 175,379$ & $\$ 596,279$ & $\$ 1,072,408$ & $\$ 1,494,860$ \\
\hline Nutrition incentives & $\$ 155,571$ & $\$ 409,339$ & $\$ 816,581$ & $\$ 884,800$ \\
\hline Average match & $89 \%$ & $69 \%$ & $76 \%$ & $59 \%$ \\
\hline \hline Participating farmers & $\mathrm{N} / \mathrm{A}$ & 1,718 & 2,279 & 3,240 \\
\hline Participating farmers markets & 26 & 116 & 225 & 306 \\
\hline Average farmers per market & $\mathrm{N} / \mathrm{A}$ & 15 & 10 & 11 \\
\hline \hline Average benefit \& incentive per farmer & $\mathrm{N} / \mathrm{A}$ & $\$ 585$ & $\$ 829$ & $\$ 734$ \\
\hline Average benefit \& incentive per farmers market & $\$ 12,929$ & $\$ 8,669$ & $\$ 8,396$ & $\$ 7,777$ \\
\hline \hline
\end{tabular}

Source: Authors' calculations of Wholesome Wave data, retrieved July 2015 from http://66.39.100.79/dvcp/

2). In 2012, farmers markets accepting federal nutrition benefits for payment received, on average, approximately US $\$ 17,000$ in benefits.

The legislation specifies that nonprofits and governments are eligible to receive FINI funds, which will be distributed as incentives matching SNAP redemptions at authorized SNAP retail locations. Given that, at the time of writing, the first round of funds has not yet been distributed, we can only speculate about the community-level detail concerning the use of FINI matching incentives. Important aspects regarding implementation ultimately depend on how the nonprofit organizations and government agencies seeking

Table 2. Number of Farmers Markets and Redemption of Federal Nutrition Benefits in Farmers Markets: U.S., 2008-2013

\begin{tabular}{lcccc}
\hline Year & $\begin{array}{l}\text { Farmers } \\
\text { markets }\end{array}$ & $\begin{array}{c}\text { Markets accepting } \\
\text { SNAP benefits }\end{array}$ & SNAP & $\begin{array}{c}\text { Senior and WIC } \\
\text { FMNP }\end{array}$ \\
\hline 2008 & \multicolumn{3}{c}{ Number } & Millions of US\$ \\
\hline 2009 & 5,685 & 750 & $\sim \$ 2.0$ & $\sim \$ 41.6$ \\
\hline 2010 & 5,274 & 936 & 4.2 & $\sim 40.4$ \\
\hline 2011 & 6,132 & 2,445 & 7.5 & 38.2 \\
\hline 2012 & 7,175 & 1,040 & 11.7 & 37.4 \\
\hline 2013 & 7,864 & 3,214 & 16.6 & 37.1 \\
\hline
\end{tabular}

Note: Does not include WIC Cash Value Vouchers (CVV) spent at market because data are not available.

Sources: Farmers Market Coalition, n.d.; USDA, AMS, 2013. grant funding will structure programs for their communities. Also key is how closely USDA, when awarding the grants, adheres to the stated priority of locally and regionally produced foods. While the majority of nutrition incentives have been used at farmers markets that tend to sell locally and regionally produced food, FINI nutrition incentives will also be distributed through food retail stores. There is precedence for their use in grocery stores, as Fair Food Network piloted the use of "double up bucks" for Michigan-grown produce in three independent grocery stores in 2013 (Fair Food Network, n.d.-b). In addition, since the nutrition incentives will be distributed via community groups, the capacity of those groups will influence the success of the program.

Farmers markets are likely to remain an important venue for FINI benefits, at least initially, largely because the nonprofits administering grassroots-based nutrition incentive programs already have the capacity to operate programs under FINI. Furthermore, lobbying by advocates of nutrition incentive programs was largely conducted by those with experience operating programs at farmers markets. That does not mean, however, that farmers 
markets will be the only venue for nutrition incentive programs. Nonprofits and government agencies may view food cooperatives, neighborhood stores, convenience shops, and small, independent grocery stores as likely other locations for matching SNAP redemptions with nutrition incentives, particularly in urban areas where such stores are common. At this point in time, little is known about the extent of participation in the FINI programs by larger, chain supermarkets. On the one hand, large supermarkets already meet the demand of many low-income consumers; in 2009, 84 percent of federal nutrition benefits were redeemed in supermarkets or supercenters (Ver Ploeg et al., 2009). Just 2 percent were redeemed in small groceries and 4 percent were redeemed in other venues, which includes farmers markets (Castner \& Henke, 2011). ${ }^{2}$ Clearly the raw numbers suggest that FINI might be able to reach a greater number of consumers through large supermarkets; the target populations are those living in impoverished urban or rural communities with few large supermarkets, and, most likely, with few farmers markets (Ver Ploeg et al., 2009). Exactly how FINI unfolds, including where the nutrition incentives can be redeemed, depends on the organizations applying for the funds and their partner retail outlets.

\section{Assessing Economic Impact: Methodology}

"Input-output" models are a commonly used method for quantifying economic impacts of government spending. The models trace expenditures through the economy, working on the assumption that of every dollar received, only a portion will be spent. A "multiplier" summarizes the total amount of economic activity created from beginning to end and is based on the proportions spent and saved, as well as on the flow of expenditures through the economy. Two methods widely used for assessing economic activity at a regional level are IMPLAN, a software package initially developed by the U.S. Forest Service and now owned by IMPLAN

\footnotetext{
${ }^{2}$ Other venues include "groceries in combination with other stores, delivery routes, farmers markets, non-profit food buying cooperatives, and wholesalers" (Castner \& Henke, 2011, p xxx).
}

Group LLC (IMPLAN Group LLC, 2012), and RIMS II, developed by the U.S. Commerce Department's Bureau of Economic Analysis (Bureau of Economic Analysis [BEA], n.d.). Both methods are easy to use, as the complexities of the sectoral flows of funds are modeled behind the scenes. Studies of the economic impact of different aspects of the food system on the community level have relied on IMPLAN (see for example, Allen, Gabe, \& McConnon, 2006; Henneberry, Whitacre, \& Agustini, 2009; Organic Trade Association, 2012; Otto \& Varner, 2005; Tootelian, Mikhailitchenko, \& Varshney, 2012). However, quantifying regional or local benefits, particularly of food systems, is a challenging task for multiple reasons, two of which are the uncertainty regarding regional boundaries and the lack of accurate data for specific regions (O’Hara \& Pirog, 2013).

This analysis relies on a different input-output model, which was specifically designed for conducting a national-level assessment of the economic benefits of food assistance. The Food Assistance National Input-Output Multiplier (FANIOM) model, developed by USDA's Economic Research Service (ERS), models linkages among domestic food assistance, agriculture, and the economy at the national level (Hanson, 2010). One appeal of the FANIOM model is its suitability to a nationallevel analysis of SNAP spending, which makes it directly applicable to this paper. Using the FANIOM input-output model, ERS researchers developed a range of multipliers that assess the effect of SNAP purchases on economic activity as measured by gross domestic product (GDP) and employment.

The multipliers take into account that federal nutrition benefit recipients tend to use their benefits right away, with the funds expended entering the economy quickly. Analysis of expenditure patterns indicate that in 2009 more than half of households used nearly all of their benefits within the first two weeks of receiving them (Castner \& Henke, 2011). Empirical research indicates that, for each dollar of SNAP benefits received, food expenditures increase by 23 to 35 percent (Hanson, 2010). The percentage of federal benefits spent on food is less than one hundred because, while households do buy more food, they also shift 
expenditure of existing funds from food to other uses, so they purchase more nonfood items as well. Given the range of empirical estimates, ERS researchers rely on a midrange consumption change of 26 percent when calculating the FANIOM multiplier (Hanson, 2010).

Using different sets of assumptions about spending, ERS developed three multipliers that can be used to predict the level of economic activity generated from the redemption of federal nutrition benefits. The estimated multipliers range from 0.89 to 1.79 , and imply that for each US $\$ 1,000$ of benefits, the economic activity created ranges from US $\$ 890$ to US $\$ 1,790$ (Table 3). The first, type I, includes the direct and indirect effects that result from SNAP expenditures. The direct effects in this case accrue to the firms producing and distributing the food purchased by the federal nutrition benefit customers. The indirect effects result from the increased demand for food products, which is heavily weighted towards farm products. The type II multiplier expands on the type I multiplier by adding the multiplicative induced effects of labor income (jobs saved and created) on economic activity. These effects come from the amount of spending on goods and services that result from the increased or preserved labor earnings. The type III multiplier adds the induced effects from capital income, which include dividends, interest, rent, retained earnings, depreciation, and profit tax (Hanson, 2010). This analysis relies on the type II multiplier, which projects the amount of economic activity associated with direct and indirect effects of the increased spending, as well as the commen-

\section{Table 3. Multipliers for SNAP's Impact on Macroeconomic Variables}

\begin{tabular}{lcc}
\hline Multiplier Type & GDP multiplier & $\begin{array}{c}\text { Jobs per million } \\
\text { US\$ GDP }\end{array}$ \\
\hline Type I & 0.89 & 9.8 \\
\hline Type II & 1.45 & 15.9 \\
\hline Type III & 1.79 & 19.8 \\
\hline
\end{tabular}

Note: GDP multiplier is the increase in GDP that results from the government's distribution of SNAP benefits. Jobs per million dollars of GDP were inferred by the authors based on work by Hanson, 2010.

Source: Hanson, 2010. surate induced effects of labor income.

The jobs impact (or employment multiplier) is measured in terms of the number of full-time, parttime and self-employed positions created or preserved. However, it is important to note that ERS suggests that the employment multiplier is more appropriate when assessing the creation of a new industry than when looking at increased household expenditure (such as increased SNAP spending). The ERS researchers state that the type III multipliers from input-output models tend to overestimate the number of jobs created when compared to other methods, such as the number of jobs per 1 percent change in GDP. Thus the estimated number of jobs created (based on the employment multiplier) likely exceeds the actual employment change.

The multipliers predict economic activity generated by what the macroeconomics literature refers to as the government's injection of new funds into the economy, also called government spending. All federal nutrition benefits are a form of government spending, and thus the multipliers project how much economic activity they will spur. We assume the funds allocated under FINI are new government spending, with an effect on the economy equivalent to SNAP expenditures.

Crucial differences exist between the assumptions underlying the FANIOM model and the food system that produces the locally and regionally produced fruits and vegetables that FINI targets. The FANIOM multipliers are based on the assumption that the food purchased is the product of conventional marketing channels. This assumption is based on the concept that agricultural products move from the farm, through the processing and distribution channels, and finally to the retail store. ERS estimates that the distribution of food expenditures is approximately 6 percent to producers, 57 percent to processors, 12 percent to distributors, and 26 percent to retailers. The first difference is that fruits and vegetables are not as highly processed as other foods that are included in the model. Second, locally and regionally produced fruits and vegetables are distributed via a short supply chain. These differences suggest that expenditures for fruits and vegetables will not be distributed along the food supply chain in the 
proportions ERS indicates. Furthermore, local and regional purchases, such as those made in farmers markets or other short supply chains, are thought to generate higher levels of economic activity, although this has not been definitively established and remains an important research question (O'Hara \& Pirog, 2013; Sadler, Clark, \& Gilliland, 2013).

An advantage of the inputoutput models is their ease of use, and this is likely why they are widely used in assessments of economic impact. There are drawbacks, however, to their use beyond those directly related to the food system. One shortcoming is the assumption that increases in sales and output have no effect on prices. Second, all firms within a sector are assumed to be identical. Thus, the multiplier, along with any of the standard input-output models (IMPLAN or RIMS II), is best interpreted as a way of describing potential economic activity of closely related spending; it provides a reasonable estimate, and possibly a lower bound, of economic benefits at a national scale.

\section{Potential Economic Activity Associated with Nutrition Incentives and Federal Nutrition Benefits}

In order to understand the potential effects of the new FINI nutrition incentives program, we assess the economic impact of the funds allocated for nutrition incentives at different matching rates. The total amount allotted (US\$100 million over 5 years) translates into US $\$ 20$ million each year. ${ }^{3}$ USDA's request for proposals does not specify a specific match percentage (Agricultural Act of 2014, n.d.). Several assumptions underlie the estimates of economic activity that follow. The first assumption is that the entire annual distribution of US $\$ 20$ million of nutrition incentives is distributed, and

3 The additional US $\$ 5$ million authorized for a portion of the years covered by the Agricultural Act of 2014 is excluded from the projections. that the entire amount is used for incentives. In practice, a portion of the US $\$ 20$ million will likely be used for administrative costs, so this represents an upper bound. Next, projections of potential economic benefits are evaluated for different levels of match, in increments of 20 cents, ranging from 20 cents per US $\$ 1$ of SNAP redeemed to a full dollar-for-dollar match (Table 4). The third assumption is that all of the incentives will be redeemed at farmers markets.

The economic benefits are sensitive to the percentage of SNAP benefits matched, as demonstrated when backing into the amount of SNAP redemption that would be needed. For example, in order to distribute the entire US $\$ 20$ million allocated for nutrition incentives in the farm bill, given the assumption that the match provided is 20 percent, participants need to redeem US $\$ 100$ million in SNAP benefits on fruit and vegetables. Note that in practice organizations will provide matches at different levels. For the sake of simplicity, the match amount given in the table can be thought of as a uniform match, provided by all organizations, or the average match provided by the participating organizations.

The level of economic activity and number of jobs created are based on both the SNAP expenditures and nutrition incentives, and use the type II multipliers as specified in Hanson (2010). Economic activity created by the SNAP benefits and nutrition incentives is about 3 times greater when the match is 20 percent, in comparison to the 100 
percent match. At a match rate of 100 percent, the nutrition incentives and SNAP expenditures would both equal US $\$ 20$ million, and with it, economic activity of US $\$ 58$ million and 922 jobs. A match of 20 percent would create US\$174 million of economic activity and 2,767 jobs. Thus there is an inverse relationship between the amount of the match and the amount of economic activity generated. When the match is small, in terms of percentage, the required redemption of SNAP is large, which is associated with a greater the level of economic activity.

\section{Farmers Market Capacity and Nutrition Incentives} Capacity in terms of market supply at markets that accept federal nutrition benefits will likely be a binding constraint on the ability of farmers markets to expand nutrition incentive programs. To demonstrate this, assuming all of the available funding for nutrition incentives is used and that the entire program is implemented at farmers markets, SNAP benefit redemption would be in the range of US $\$ 20$ million to US $\$ 100$ million, depending on the match share (see Table 4). In comparison, in 2013 (see Table 2), approximately US $\$ 20$ million of SNAP benefits were redeemed at farmers markets. Thus, with the exception of the 100 percent match, the dollar value of SNAP benefits used at farmers markets would increase over the baseline. Furthermore, at a 20 percent match, the value of SNAP benefits redeemed would increase fivefold over the 2013 baseline, to US $\$ 100$ million. Farmers markets, however, may be unable to process the higher amounts of SNAP benefits and nutrition incentives implied in these scenarios. Because fewer than half of farmers markets accepted federal nutrition benefits in 2012, a natural answer is to increase the number of farmers markets accepting SNAP. Yet this may not be a plausible solution, since the farmers markets currently accepting SNAP benefits are also those with the greatest capacity to administer the benefits.

Capacity issues are also associated with the supply of local and regional fruits and vegetables. With the heightened focus of FINI on local and regional production, the ability to meet this demand depends on whether farmers either increase their production or shift some of their sales into local and regional marketing channels. Research on existing community-based programs suggests that in markets with nutrition incentives farmers' sales are higher, and that farmers are increasing production to meet the demand of their customers at the farmers markets (Oberholtzer et al., 2012). The growth in demand that might be spurred by FINI has the potential to increase farmers' sales to local markets, but distribution, storage, aggregation, and labor are examples of obstacles facing farmers who seek to market their products locally. Regional food hubs may be instrumental in bridging the needs of retailers and farmers. However, many smaller independent grocers-particularly those currently offering inadequate amounts of healthy food for sale-may be unable to shift their buying patterns or even find local and regional produce. This suggests that success may rest in the hands of the community organizations and their efforts to work with farmers, retailers, and distributors. One unfortunate outcome of the FINI program could be that smaller stores might be unable to adapt to the program in terms of increasing their produce offerings, or might end up relying on fruits and vegetables that are not locally or regionally produced.

\section{Competing Goals and the Relative Importance of Economic Benefits}

The combination of nutrition incentives, farmers markets, and underserved communities has much promise: greater financial and geographic access to healthy foods for underserved consumers and new markets for farmers are the two most obvious. Additional potential benefits of the FINI program are adding dollars of economic activity and job creation. One currently unexplored area is the sensitivity of consumption of fruits and vegetables to the size of the match a consumer receives. While this research has not been undertaken, related research is suggestive. Price reductions or coupons may encourage increased consumption of fresh fruits and vegetables (Dong \& Leibtag, 2010; Dong \& Lin, 2009; Guthrie, Lin, Ver Ploeg, \& Frazao, 2007). Prior research suggests that produce consumption does not respond to price reductions until an income threshold has been passed; empirical work suggests this point is where household 
income reaches 130 percent of the poverty level (Stewart \& Blisard, 2008). One implication is that consumers are sensitive to the amount of the nutrition incentive, but the sensitivity appears to vary with income level. Those with lower income may need larger incentives before their food purchasing and consumption behaviors respond. In practice, this may translate to difficulty in reducing food insecurity for the poorest households.

We conclude that if the policy goal is to encourage people to eat more fruits and vegetables, nutrition incentives should be larger. However, larger incentives create smaller economic benefits. At the same time, a smaller match means that a greater number of consumers receive nutrition incentives. The trade-offs are clear: the greater the incentive, the more responsive consumption is, but the smaller the economic impact. Similarly, there is tension between the number of participants in nutrition incentive programs and the potential increase in consumption of fruits and vegetables. Research to determine the right size of the nutrition incentive would guide policy-makers in setting the best match percentage. The ability to fine-tune the match percentage, perhaps by neighborhood characteristics, would balance the needs of communities in terms of food access, economic activity, number of people that FINI potential reaches, and expenditure of federal nutrition benefits.

Finally, markets consist of both supply and demand. While there is no guarantee that purchases of fruits and vegetables will increase in response to the nutrition incentives, what happens if there is an increase? Will there be a supply response at the retail level, including a removal or reduction of the barriers that are currently preventing food purveyors from offering fruits and vegetables for sale in underserved communities? While FINI does not explicitly address supply, the availability of fruits and vegetables is critical to the success of this program. We suggest that the next efforts of grassroots organizations and policy-makers more explicitly focuses on farm-level supply factors.

\section{Acknowledgements}

The authors thank two anonymous JAFSCD reviewers for helpful comments and suggestions.

\section{References}

Agricultural Act of 2014, \4208. (n.d.). Food Insecurity Nutrition Incentive. HR 113-333. Retrieved from http://thomas.loc.gov/cgi-bin/cpquery/?\&dbname $=\mathrm{cp} 113 \& \mathrm{sid}=\mathrm{cp} 113 \mathrm{bmWzI} \& \mathrm{refer}=\& \mathrm{r} \mathrm{n}=\mathrm{hr} 333.11$ 3\&item $=\& \& \& s e l=$ TOC $566460 \&$

Ahearn, M., \& Sterns, J. (2013). Direct-to-consumer sales of farm products: Producers and supply chains in the Southeast. Journal of Agricultural and Applied Economics, 45(3), 497-508. http://purl.umn.edu/155424

Allen, T. G., Gabe, T. M., \& McConnon, J. C. (2006). The economic contribution of agri-tourism to the Maine economy (REP Staff Paper No. 563). Orono, Maine: University of Maine, Department of Resource Economics and Policy. Retrieved from https://www.uvm.edu/ snrvtdc/agritourism/ UMaine repstaffpaper563.pdf

Andrés, J. (2014, August 28). José Andrés interviews fellow chef Michel Nischan [Blog post]. Retrieved from http://theplate.nationalgeographic.com/ 2014/08/28/jose-andres-interviews-fellow-chefmichel-nischan/

Barnhill, A. (2011). Impact and ethics of excluding sweetened beverages from the SNAP program. American Journal of Public Health, 101(11), 2037-2043. http://dx.doi.org/10.2105/AJPH.2011.300225

Baronberg, S., Dunn, L., Nonas, C., Dannefer, R., \& Sacks, R. (2013). The impact of New York City's Health Bucks Program on Electronic Benefit Transfer spending at farmers markets, 2006-2009. Preventing Chronic Disease, 10, E163. http://dx.doi.org/10.5888/pcd10.130113

Bartlett, S., Klerman, J., Wilde, P., Olsho, L., Blocklin, M., Logan, C., \& Enver, A. (2013). Healtby Incentives Pilot (HIP) interim report. Washington, D.C.: USDA, FNS, Office of Policy Support. Retrieved from http://www.fns.usda.gov/sites/default/files/HIP Interim.pdf

Blumenthal, S. J., Hoffnagle, E. E., Leung, C. W., Lofink, H., Jensen, H. H., Foerster, S. B., ...Willett, W. C. (2014). Strategies to improve the dietary quality of Supplemental Nutrition Assistance Program (SNAP) beneficiaries: An assessment of stakeholder opinions. Public Health Nutrition, 17(12), 2824-2833. http://dx.doi.org/10.1017/S1368980013002942 
Bureau of Economic Analysis. (n.d.). Regional InputOutput Modeling System (RIMS II). Retrieved September 2013 from https://www.bea.gov/regional/rims/index.cfm

Castner, L., \& Henke, J. (2011). Benefit redemption patterns in the Supplemental Nutrition Assistance Program: Final report. Washington, D.C.: U.S. Department of Agriculture, Food and Nutrition Service, Office of Research and Analysis. Retrieved from http://www.fns.usda.gov/sites/default/files/ ARRASpendingPatterns.pdf

Dimitri, C., L. Oberholtzer \& M. Nischan. (2013). "Reducing the geographic and financial barriers to food access: perceived benefits of farmers markets and monetary incentives." Journal of Hunger and Environmental Nutrition. Vol. 8. Issue 4. pp 429-444. DOI:10.1080/19320248.2013.840547

Dimitri, C., Oberholtzer, L., Zive, M., \& Sandolo, C. (2015). Enhancing food security of low-income consumers: An investigation of financial incentives for use at farmers markets. Food Policy, 52, 64-70.

Dong, D., \& Leibtag, E. (2010). Promoting fruit and vegetable consumption: Are coupons more effective than pure price discounts? (Economic Research Report No. ERR-96). Washington, D.C.: USDA, Economic Research Service. Retrieved from http://www.ers.usda.gov/publications/erreconomic-research-report/err96.aspx

Dong, D., \& Lin, B.-H. (2009). Fruit and vegetable consumption by low-income Americans: Would a price reduction make a difference? (Economic Research Report No. ERR-70). Washington, D.C.: USDA, Economic Research Service. Retrieved from http://www.ers.usda.gov/publications/erreconomic-research-report/err70.aspx

Fair Food Network. (n.d.-a). Double Up Food Bucks.

Retrieved October 2014 from http://www.fairfoodnetwork.org/what-wedo/projects/double-up-food-bucks

Fair Food Network. (n.d.-b). Double Up Grocery Project. Retrieved October 2014 from http://www.fairfoodnetwork.org/what-wedo/improving-healthy-food-access/double-upfood-bucks/grocery-project

Farmers Market Coalition. (n.d.). Supplemental Nutrition Assistance Program. Retrieved July 2015 from http:// farmersmarketcoalition.org/ advocacy/snap/
Freedman, D. A., Mattison-Faye, A., Alia, K., Guest, M. A., \& Hébert, J. R. (2014). Comparing farmers' market revenue trends before and after the implementation of a monetary incentive for recipients of food assistance. Preventing Chronic Disease, 11, 130347. http://dx.doi.org/10.5888/pcd11.130347

Guthrie, J., Lin, B.-H., Ver Ploeg, M., \& Frazao, E. (2007). Overview: Can food stamps do more to improve food choices? An economic perspective (Economic Information Bulletin No. EIB 29-1). Washington, D.C.: USDA, Economic Research Service.

Retrieved from http://www.ers.usda.gov/ publications/eib-economic-informationbulletin/eib29-1.aspx

Hanson, K. (2010). The Food Assistance National InputOutput Multiplier (FANIOM) model and the stimulus effects of $S N A P$ (Economic Research Report No. ERR-103). Washington, D.C.: USDA, Economic Research Service. Retrieved from http://www.ers.usda.gov/publications/erreconomic-research-report/err103.aspx

Henneberry, S. R., Whitacre, B., \& Agustini, H. N. (2009). An evaluation of the economic impacts of Oklahoma farmers markets. Journal of Food Distribution Research, 40(3), 64-78. http://purl.umn.edu/99760

Illinois Department of Agriculture. (n.d.). IL Product FFA Challenge - overview. Retrieved July 2015 from http://www.agriculture.illinois.gov/ffa/ overview.html

IMPLAN Group LLC [formerly Minnesota IMPLAN Group, Inc.]. (2012). Home page. Retrieved September 2013 from http://www.implan.com

Just, D. R. (2011). Behavioral economics and the food consumer. In J. L. Lusk, J. Roosen, and J. F. Shogren (Eds.), The Oxford Handbook of the Economics of Food Consumption and Policy (pp. 99-118). Oxford University Press. http://dx.doi.org/10.1093/ oxfordhb/9780199569441.013.0005

Klerman, J. A., Bartlett, S., Wilde, P., \& Olsho, L. (2014). The short-run impact of the Healthy Incentives Pilot program on fruit and vegetable intake. American Journal of Agricultural Economics, 96(5), 1372-1382. http://dx.doi.org/10.1093/ajae/aau023 
Lindsay, S., Lambert, J., Penn, T., Hedges, S., Ortwine, K., Mei, A.,...Wooten, W. J. (2013). Monetary matched incentives to encourage the purchase of fresh fruits and vegetables at farmers markets in underserved communities. Preventing Chronic Disease, 10, 130124. http://dx.doi.org/10.5888/pcd10.130124

Low, S. A., \& Vogel, S. (2011). Direct and intermediated marketing of local foods in the United States (Economic Research Report No. ERR-128). Washington, D.C.: U.S. Department of Agriculture, Economic Research Service. Retrieved from http://www.ers.usda.gov/publications/erreconomic-research-report/err128.aspx

Market Umbrella. (2012). MarketMatch SNAP Incentive Program. Retrieved from http://www.marketumbrella.org/uploads/casestudies/case-study-marketmatch-snap-incentive.pdf

Martinez, S., Hand, M. S., Da Pra, M., Pollack, S., Ralston, K., Smith, T.,...Newman, C. (2010). Local food systems: Concepts, impacts, and issues (Economic Research Report No. ERR-97). Washington, D.C.: USDA, Economic Research Service. Retrieved from http://www.ers.usda.gov/publications/erreconomic-research-report/err97.aspx

May, C. (2013, August 1). Restrict food stamps for junk food? Health organizations urge USDA to test limits. The Daily Caller. Retrieved from http://dailycaller.com/2013/08/01/restrict-foodstamps-for-junk-food-health-organizations-urgeusda-to-test-limits/

Oberholtzer, L., Dimitri, C., \& Schumacher, G. (2012). Linking farmers, healthy foods, and underserved consumers: exploring the impact of nutrition incentive programs on farmers and farmers' markets. Journal of Agriculture, Food Systems, and Community Development, 2(4), 63-77.

O’Hara, J. K., \& Pirog, R. (2013). Economic impacts of local food systems: Future research priorities. Journal of Agriculture, Food Systems, and Community Development, 3(4), 35-42. http://dx.doi.org/10.5304/jafscd.2013.034.003

Organic Trade Association. (2012, April 25). Organic foods industry creates more than a half million jobs [Press release]. Retrieved from http://www.organic newsroom.com/2012/04/organic foods industry creates.html
Otto, D., \& Varner, T. (2005). Consumers, vendors, and the economic importance of Iowa farmers' markets: An economic impact survey analysis. Ames, Iowa: Leopold Center for Sustainable Agriculture, Iowa State University. Retrieved from https://www.leopold.iastate.edu/ pubs-and-papers /2005-05-farmers-markets

Park, T., Mishra, A. K., \& Wozniak, S. J. (2014). Do farm operators benefit from direct to consumer marketing strategies? Agricultural Economics, 45(2), 213-224. http://dx.doi.org/10.1111/agec.12042

Sadler, R. C., Clark, M. A. R., \& Gilliland, J. A. (2013). An economic impact comparative analysis of farmers' markets in Michigan and Ontario. Journal of Agriculture, Food Systems, and Community Development, 3(3), 61-81. http://dx.doi.org/10.5304/jafscd.2013.033.009

Schumacher, G., Nischan, M., \& Simon, D. B. (2011). Healthy food access and affordability: "We can pay the farmer or we can pay the hospital." Maine Policy Review, 20(1), 124-139. http://digitalcommons.library.umaine.edu/mpr

SNAP to Health. (n.d.). SNAP at farmers' markets.

Retrieved October 2014 from http://www.snaptohealth.org/snapinnovations/snap-at-farmers-markets/

Stewart, H., \& Blisard, N. (2008). Are lower income consumers willing and able to budget for fruits and vegetables? (Economic Research Report No. ERR54). Washington, D.C.: U.S. Department of Agriculture, Economic Research Service. Retrieved from http://www.ers.usda.gov/publications/erreconomic-research-report/err54.aspx

Sugiyama, T., \& Shapiro, M. F. (2014). The growing socioeconomic disparity in dietary quality: Mind the gap. JAMA Internal Medicine, 174(10), 1595-1596. http://dx.doi.org/10.1001/jamainternmed.2014.30 $\underline{48}$

Tootelian, D. H, Mikhailitchenko, A., \& Varshney, S. B. (2012). Can producing and marketing healthy foods create a healthy economy? Journal of Food Products Marketing, 18(3), 242-256. http://dx.doi.org/10.1080/10454446.2012.668376

Uematsu, H., \& Mishra, A. K. (2011). Use of direct marketing strategies by farmers and their impact on farm business income. Agricultural and Resource Economics Review, 40(1), 1-19. http://purl.umn.edu/105457 
U.S. Department of Agriculture [USDA], Agricultural Marketing Service [AMS]. (2013). Farmers markets and local food marketing. Retrieved from http://www.ams.usda.gov/AMSv1.0/ams.fetchTe mplateData.do?template $=$ TemplateS\&leftNav $=\mathrm{Wh}$ olesaleandFarmersMarkets\&page $=$ WFMFarmersM arketGrowth\&description $=$ Farmers $\% 20$ Market $\% 2$ 0 Growth\&acct $=$ frmrdirmkt

USDA, Economic Research Service [ERS]. (2014). Agricultural Act of 2014: Highlights and implications: Nutrition. Retrieved from http://www.ers.usda.gov/agricultural-act-of-2014highlights-and-implications/nutrition.aspx

USDA, Food and Nutrition Service [FNS]. (2013, April 29). USD $A$ expands support for farmers markets to accept Supplemental Nutrition Assistance Program benefits [Press Release No. FNS-0008.13]. Retrieved from http://www.fns.usda.gov/pressrelease/2013/fns$\underline{000813}$

USDA, FNS. (2014). Supplemental Nutrition Assistance Program. Retrieved from http://www.fns.usda. gov/snap/supplemental-nutrition-assistanceprogram-snap
USDA, FNS. (2015). Program data: Overview. Retrieved from http://www.fns.usda.gov/pd/overview

USDA, National Institute of Food and Agriculture [NIFA]. (2014). Food Insecurity Nutrition Incentive (FINI) grant program: 2014/2015 request for applications (RFA). Retrieved from http://nifa.usda.gov/ sites/default/files/rfa/1415_FINI.pdf

Ver Ploeg, M., Breneman, V., Farrigan, T., Hamrick, K., Hopkins, D., Kaufman, P.,...Tuckermanty, E. (2009). Access to affordable and nutritious foodMeasuring and understanding food deserts and their consequences: Report to Congress (Administrative Publication No. AP-036). Retrieved from http://www.ers.usda.gov/publications/apadministrative-publication/ap-036.aspx

Wholesome Wave. (n.d.). Wholesome Wave's Double Value Coupon Program. Retrieved from http://www.whole somewave.org/wp-content/uploads/2014/07/ 2014 double value coupon program.pdf 